Dementia training programmes for staff working in general hospital settings - a systematic review of the literature

Anthony SCERRI MGer, M.HSc (HSM), RN (corresponding author) Assistant Lecturer

Department of Nursing,

Faculty of Health Sciences,

University of Malta, Malta

Tel No: 0035623401178

Anthea INNES PhD,

Professor,

Faculty of Social Sciences;

University of Stirling, UK,

Salford Institute for Dementia,

University of Salford,

Manchester, UK

Charles SCERRI PhD

Senior Lecturer,

Department of Pathology,

Faculty of Medicine and Surgery,

University of Malta, Malta 
Funding: No funding declared

\title{
Dementia training programmes for staff working in hospital settings - a systematic review of the literature
}

\begin{abstract}
:
Objectives: There has been an increased interest in dementia training programmes directed to general hospitals, partly due to the reported lack of staff training that may be contributing to poor quality of care. Although literature describing and evaluating training programmes in hospital settings increased in recent years, there are no reviews that summarise these programmes. This review sought to address this, by collecting the current evidence on dementia training programmes directed to staff working in general hospitals.
\end{abstract}

Method: Literature from five databases (PubMed, Academic Search Complete, PsychInfo, CINAHL and AgeLine) were searched, based on a number of inclusion criteria. The selected studies were summarised and data was extracted and compared using narrative synthesis based on a set of pre-defined categories. Methodological quality was assessed using Kmet, Lee \& Cook (2004) criteria.

Results: Fourteen peer-reviewed studies were identified with the majority being pre-test post-test investigations. No randomised controlled trials were found. Methodological quality was variable with selection bias being the major limitation. There was a great variability in the development and mode of delivery although, interdisciplinary ward based, tailor-made, short sessions using experiential and active learning, were the most utilized approaches. The majority of the studies mainly evaluated learning, with few studies evaluating changes in staff behaviour/practices and patients' outcomes. 
Conclusion: This review indicates that high quality studies are needed that especially evaluate staff behaviours and patient outcomes and their sustainability over time. This review also highlights measures that could be used to develop and deliver training programmes in hospital settings.

Keywords: dementia and cognitive disorders, training and educational programmes, institutional care

\section{Introduction}

According to the World Alzheimer Report of 2015 (Prince et al., 2015), 46.8 million people worldwide were living with dementia in 2015. This figure will almost double every 20 years, reaching 74.7 million in 2030 and 131.5 million in 2050. Due to the varying co-morbid conditions, persons with dementia may require the need for referral and admission to an acute hospital. At any time, a quarter of the patients in an acute hospital are persons with dementia or cognitive impairment (Lakey, 2009; Royal College of Psychiatrists, 2011). Moreover, patients with dementia may account to as much as $42 \%$ of patients aged over 70 years in acute hospitals (Lyketsos et al., 2000; Sampson, Blanchard, Jones, Tookman \& King, 2009).

There is ample evidence that the quality of care of patients with dementia in hospital settings is far from optimal (Zekry et al., 2008) and can be very challenging (Clissett, Davina, Rowan, \& John, 2013). The Royal College of Psychiatrists $(2011,2013)$ carried out two national audits of dementia care in general hospitals in UK and identified 'disappointing results' in the first Audit (2011). Although the second National Audit found that positive initiatives were taken, including the development of Dementia Champions and the collection of a life history (personal information) about persons with dementia when in hospital together with the reduction in the use of anti-psychotic medications, more needs to be done. Nevertheless, a number of negative findings were also reported including a dearth of proper assessment for 
delirium risk and cognitive function and a general lack of staff awareness of how best to care for these patients, indicating a huge need for better staff training and support. The report showed that person-centred dementia care training was delivered in only $23 \%$ of the hospital audited. The need for dementia care training in hospital settings to improve the quality of care of these patients has been highlighted in national dementia strategies such as National Dementia Strategy in England (Department of Health, 2009) and the National Strategy for Dementia in the Maltese Islands (Scerri, 2015) as well as the National Institute of Clinical Excellence guidelines (NICE, 2007).

Most of the studies and reviews on dementia care training programmes were developed to provide nursing and care staff with the necessary skills to reduce challenging behaviours in individuals with dementia in long-term care settings (Moyle, Hsu, Lieff, \& Vernooij-Dassen, 2010). Two reviews (McCabe, Davison \& George, 2007; Spector, Orrell \& Goyder, 2013) concluded that staff training programmes can reduce Behavioural and Psychological Symptoms of Dementia (BPSD) in dementia residents. The training programmes also had a positive impact on the staff in terms of knowledge, perceived ability to manage BPSD, decreased stress and reduced staff turnover. However, both reviews highlighted the methodological weaknesses and low quality of the studies. Similarly, Kuske et al. (2007), in a systematic review of staff training programmes on dementia care, commented that due to these methodological weaknesses and a lack of follow-ups, it was difficult to conclude that these programmes have successfully been able to make a difference in practice.

Irrespective of these limitations, evidence on the effectiveness of dementia care training in long-term care wards is available (Kuske et al., 2007; McCabe et al., 2007). However, there is still limited evidence of whether training sessions have the same impact in hospitals, even though interest in developing these programmes in these settings is increasing. For example, the Royal College of Nursing together with academics and senior nurse managers in nine 
NHS trusts providing acute care worked collaboratively to improve the experience of patients with dementia and their family during their hospital stay (Brooker et al., 2014). The majority of the participating trusts developed and implemented a staff training programme on dementia care, showing that this approach was the most favoured intervention. However, although this programme showed positive outcomes, the heterogeneity of interventions and methods of evaluation makes it difficult to ascertain whether the outcomes were the result of the intervention.

Two reviews (Dewing \& Dijk, 2014; Moyle et al., 2008) discussed current practices in the care of older persons with dementia in general hospital settings. Dewing \& Dijk (2014) summarised descriptive studies, discussing themes such diagnosis, staff knowledge and attitudes, experiences of persons with dementia, family carers and staff. Similarly, Moyle et al. (2008) mainly focused on theoretical literature and identified a number of principles and models of care that are essential for best practice in the care of older people with dementia that can be used in hospital settings. Nevertheless, both reviews did not provide a detailed overview of published studies that developed and evaluated dementia training programmes in hospital settings. Moreover, multi-component interventions make it hard to elucidate what makes the difference in outcome during evaluation. Although, Dewing \& Dijk (2014) identified a number of studies in their review, an evaluation of the quality of these studies has never been sought. Consequently, this review will specifically focus on peer-reviewed studies that evaluate staff training programmes in hospital settings where the primary intervention was the training programme.

In summary, with the increased dementia prevalence, more persons with dementia will require hospital care. However, hospital care for persons with dementia is challenging partly because staff are not trained enough. Although, studies that evaluate the effectiveness of staff training programmes in long-term care are available, there is still limited evidence on what is 
practical to implement in terms of content, delivery models (Surr, Smith, Crossland \& Robins, 2016) and methods used to evaluate training programmes in hospital settings (Dewing \& Dijk, 2014). This review sought to address this gap in the literature by critically appraising published training programmes directed to hospital staff, with a focus on their development, content and mode of delivery, as well as levels of evaluation used, in order to direct educators, researchers and hospital administrators interested in developing and evaluating such programmes.

\section{Aim and objectives}

The study was directed by the following research question:

What is the current evidence on dementia training programmes directed to staff working in general hospital settings?

More specifically, the authors sought the answer the following objectives:

1. What is the quality rating of the selected studies?

2. What are the characteristics of the training programmes in the selected studies?

3. Based on Kirkpatrick's Evaluation Framework (2009), at which level are these training programmes evaluated?

4. How effective are these training programmes at different levels?

5. What are the challenges and solutions in developing and evaluating dementia training programmes in hospital settings?

\section{Methods}

Definition of a general hospital 
In the context of this review, a broad definition of the term 'general hospital' was taken, consisting of 'a hospital not specialising in the treatment of a particular illness or of patients of a particular sex or age group' (Collins English Dictionary, 2016). Therefore, psychiatric and other specialised hospitals were excluded from this review.

\section{Search strategy}

Five commonly used databases namely PubMed, Academic Search Complete, PsychInfo, CINAHL with full texts and AgeLine were searched. The Medical Subject Headings (MeSH) 'dementia' OR 'Alzheimer' AND 'hospitals' AND 'training' AND 'education' AND 'evaluation' were inputted in each database (Appendix). Titles and abstracts were initially reviewed to identify potentially relevant articles and reference lists of selected articles were screened.

\section{Eligibility criteria}

\section{Inclusion criteria}

Studies with the following criteria were included:

- carried out in general hospital settings/wards as previously defined

- reporting interventions that consisted predominantly of a training/educational programme for staff working in hospital settings

- identified in peer-reviewed journals

- written in English language

- with evaluation designs composed mainly of a quantitative component

\section{Exclusion criteria}

Studies with the following criteria were excluded: 
- carried out in long-term care facilities including residential homes/nursing homes/ assisted living settings and day hospitals

- absence of evaluation data

- focusing mainly on the effectiveness of mental health liaison posts or specialist units in hospital settings

- reports or projects from grey literature

- investigating educational/training interventions in undergraduate studies

- investigating educational/training interventions directed to patients, family members or the lay public

- programmes that focus predominantly on staff training on delirium or other geriatric syndromes other than dementia.

\section{Quality assessment}

Eleven quality criteria from Kmet, Lee \& Cook (2004) were used (Table 1). Since none of the identified studies were randomised controlled trials, three out of 14 criteria found on this checklist focusing on randomisation and blinding were excluded. Each study was assigned a score according to whether they fully met the criteria (2 points), partially met the criteria (1 point), or not at all (0 points). Summary scores were obtained by calculating the total sum attained divided by the maximum possible score of 22 .

\section{Analysis}

Owing to the heterogeneity of the training programmes, participants and outcome measures, the quantitative synthesis (meta-analysis) approach was not considered to be appropriate and the guidelines for developing narrative synthesis as suggested by Popay et al. (2006) were used. Kirkpatrick's four-level training evaluation model was used to guide in the selection of the studies and to contribute to the interpretation of the review findings (Kirkpatrick, 2009). 
Moreover, similar reviews were used to identify the theoretical models on which these studies were based upon, that could be equally applied to this study. A preliminary synthesis was developed in a table format that described the studies according to a set of predefined criteria. Eventually, relationships were explored within and between studies and the training programmes and synthesised by using qualitative case descriptions (Light \& Pillemer, 1984). The strategies used to develop the programme, the mode of delivery, the duration of the programme and the characteristics of the participants/facilitators was extracted for each programme and compared with one another. In addition, the effectiveness of the training programmes was compared by categorising the studies according to Kirkpatrick's Evaluation Framework (2009). This model has previously been adopted for appraisal of the evidence for reported training programmes to staff in supporting people with disability (Smidt, Balandin, Sigafoos \& Reed, 2009) and in identifying what works in dementia care training (Surr et al., n.d.). The selected studies were then categorised according to four levels of training evaluation that is whether the evaluation of the programme was directed to one or more of these levels (Figure 1). Evidence of the robustness of the synthesis was sought by assessing the methodological quality of the selected studies as discussed above in order to draw conclusions about the strength of the evidence.

The initial search was carried out by AS. A further independent search was carried out by another author (CS) and yielded similar findings. All three authors evaluated the initial suitability of each study. Each selected article was read in full by AS and data extraction and synthesis was carried out by tabulations (Table 1) as suggested by Popay et al. (2006) and reviewed by the other two authors (CS, AI). Data consisted of information related to the development and implementation of the training programmes as well the results obtained from the evaluation. Further data extraction and analysis was done by grouping and critically appraising the data according to the predefined categories as highlighted above. 


\section{Results}

\section{Results of the search strategy}

The initial search retrieved 496 hits. After removing duplicates (53), the titles and abstracts were read. Twenty-eight potentially relevant articles were identified after applying the inclusion/exclusion criteria. These articles were read and further assessed for eligibility. Five articles were excluded as these mostly focused on training intervention in nursing homes/long-term care wards. In six studies, evaluation data was not clearly reported, two studies focused on evaluation of staff learning needs whilst another study was directed to staff/patient experiences. In a further two studies, the training programme was part of a complex intervention (e.g. introduction on specialised care units in acute hospitals) so that staff training constituted only a small part of the intervention.

Fourteen studies were thus selected (Table 2) consisting of 10 training programmes with four studies being a repeat of the original interventions with amendments. Nine studies used a pretest, post-test design (Banks et al., 2014; Elvish et al., 2015; Elvish et al., 2016; Horner, Watson, Hill \& Etherton-Beer, 2013; Galvin et al., 2010; Palmer et al., 2014; Teodorczuk, Mukaetova-Ladinska, Corbett \& Welfare, 2014; Surr et al., 2016; Wesson \& Chapman, 2010;), four studies adopted a post-test only design (Crabtree \& Mack, 2010; McPhail, Traynor, Wikstrom, Brown, \& Quinn, 2009; Nayton et al, 2014; Waugh, Marland, Henderson, Robertson \& Wilson, 2011) whilst the remaining was a case-control study (Smythe et al., 2014). Studies were carried out in hospitals in England (6 studies), Scotland (3 studies), Australia (3 studies) and in the United States of America (2 studies).

\section{Quality assessment of selected studies}


Table 1 shows the quality rating assessment scores of the selected studies. The median quality score was 0.57 , ranging from 0.18 to 0.91 indicating a considerable variability in the quality. Using a similar classification described by Spector, Revolta \& Orrell (2016) in which studies were categorised with low $(<0.6)$, medium $(0.6-0.8)$ or high-quality $(>0.8)$ scores, three studies (Elvish et al., 2015; 2016; Surr et al., 2016) were found to be of high quality, four studies were of medium quality (Galvin et al., 2010; Palmer et al., 2014; Banks et al., 2014; Teodorczuk et al., 2014) whilst the remaining studies were of poor quality. In the medium and poor quality studies, it was not clear how the participants were selected to attend the training programmes whilst in others a purposive sample was used leading to selection bias. Moreover, most of studies did not control for any confounding variables such as type of occupation or years of experience of the participants. In addition, population size was not reported in most studies whilst power analysis was conducted in only two studies. Since most of the studies had small sample sizes, the findings obtained may not be generalizable to the population of staff working in hospital settings. Compared to high quality studies, medium and low quality studies also had insufficient detail in the reported results whilst conclusions were not always clearly supported by the results obtained.

\section{Characteristics of the training programmes}

\section{Development of the programmes}

Different strategies were adopted in developing the programmes with the most common being a review of the current literature, the use of pre-developed training packages/resources and a training needs analysis of the participants conducted prior to the training. The educational packages and resources used varied widely between programmes, most of which were developed from national experts in dementia care and were mainly focused on best practices and guidelines related to the care of persons with dementia in hospital settings. 
Ten of the 14 studies also based their training programmes on needs analysis. This was carried out prior to the implementation of the programme using focus groups with hospital staff (Elvish et al., 2015; Galvin et al., 2010; Smythe et al., 2014), discussions with hospital managers (Sur et al., 2016) or a survey method (Crabtree \& Mack, 2010; McPhail et al., 2009). Other stakeholders were consulted including mental health specialists, patients and family carers (Elvish et al., 2015, 2016; Teodorczuck et al., 2014). Nayton et al. (2014) adopted the most comprehensive method to develop the programme consisting of training outcomes obtained from the administration staff, an audit of staff perceived attitudes and environmental review, discussion with daily caregivers, a review of the literature and expert opinion and reflection following the evaluation of each session. Unlike other studies with a fixed content, the same authors also adopted an iterative approach so that the programme could be modified in terms of content and mode of delivery following participant feedback.

\section{Content and theoretical models used in the programme}

Content varied widely between programmes with a number taking a more comprehensive overview and including information such as prevalence of dementia and differential diagnosis based on the medical model (Galvin et al., 2010; McPhail et al., 2009; Palmer et al., 2014; Teodorczuk et al., 2014) whilst others focused more on psychosocial areas. Using Spector, Orrell and Goyder (2013) classification of the theoretical models in dementia care training (i.e. behavioural-oriented approaches, communication approaches, person-centred approaches, emotion-oriented approaches and other approaches), it was evident that the most used theoretical approach was the person-centred care model developed by Kitwood (1997) (Burns et al., 2014; Elvish et al., 2015, 2016; Surr et al., 2016) with a focus on the lived experience of persons with dementia and their life history. In many of the programmes there was an attempt not only to provide knowledge and skills but also to empower hospital staff in initiating a number of changes in their workplace by acting as change agents. Thus, although 
all programmes had a didactic component, other practice development strategies were employed such as experiential learning using clinical placements in mental health settings (Banks et al., 2014; Crabtree \& Mack, 2010; Smythe et al., 2014; Waugh et al., 2011) and action learning using active teaching approaches (Palmer et al., 2014; Teodorczuk et al., 2014; Waugh et al., 2011). For example, drawing from the experience of the previous Dementia Friendly Hospital Initiative Education programme (Galvin et al., 2010), Palmer et al. (2014) included more videos and case studies that encouraged group discussion and reflection whilst reducing the didactic content.

Whilst in the majority of the studies a single level of training was provided for all hospital staff, in two studies (Crabtree et al., 2010; Surr et al., 2016), a two-level training was delivered consisting of an initial awareness raising to all staff and a more advanced programme for selected staff. Compared to the awareness raising programme, the advanced programme in both studies was more exhaustive although different approaches were used whilst in Surr et al. (2016), the intermediate programme provided more in-depth knowledge, Crabtree's programme (2010) was more based on experiential learning in mental health settings. This continues to highlight the variability in content and methods used in developing these programmes.

Sustainability of the programme was sought in only two studies. Nayton et al. (2014) used a post-programme workshop whilst participants in Waugh et al. (2011) initiated a dementia awareness group to foster continuing changes in practice.

\section{Implementation of the training programme}

Delivery of the programmes varied widely between studies. For example, duration varied from 2 hours in Wesson \& Chapman (2010) to 12 days (Waugh et al., 2011), although the latter mainly consisted of clinical placement hours in the 'enhanced' level of training. Even 
though the duration of training varied considerably, there was some congruence in the methods that authors used to improve staff attendance by maintaining some flexibility in the mode of delivery. A commonly used method consisted of delivering repeated sessions of around 30-45 minutes. However, Elvish et al. (2016) preferred a whole day session when the second roll-out was delivered. Nayton et al. (2014) used a combination of the two approaches.

Most of the programmes, consisted of face-to-face classroom based sessions that included a training manual. E-learning was used in Banks et al. (2014) to supplement the materials presented with an online forum in which participants were encouraged to engage prior to each session. The same authors reported that the online experience was challenging to the staff. Similarly, Horner et al. (2013) used a self-directed e-learning programme consisting of three online models even though the uptake of this delivery method was found to be poor. These studies indicate that e-learning may not be feasible in this setting, especially when resources such as the participants' time and internet access are limited and staff are not familiar with the use of information technology platforms.

\section{Characteristics of the participants}

All studies except for one (Horner et al., 2013) were targeted to an interdisciplinary audience over a wide range of professions (nurses, physiotherapists, occupational therapists, social workers, doctors and pharmacists) even though the majority of the participants in the study came from the nursing profession. In two studies (Palmer et al., 2014; Wasson \& Chapman, 2010), the direct presence of the hospital administrators was encouraged. However, only few studies included ancillary staff such as porters, clerks, health assistants, security staff and pastors. Considering that such staff come in contact with dementia patients on a frequent basis, it is disappointing that these occupations were not targeted more often. 


\section{Characteristics of the facilitators}

Although in the majority of the studies, training was facilitated by the authors, in some programmes other persons were involved. Mental health nurses acted as mentors in the Dementia Champions programme (Banks et al., 2014) whilst a psychiatric liaison team was directly involved in running the sessions in Wesson \& Chapman (2010). In Galvin (2010) and Palmer et al. (2014) the sessions were presented by a member of the Alzheimer's Association or a volunteer dementia expert. In Elvish et al. (2016), researchers initially trained 35 hospital staff who in turn trained their colleagues. This cascading effect was found to be equally effective when compared to the original study during which staff were trained by the authors (Elvish et al., 2015). No considerable differences were reported in whether facilitators were academics, clinical experts from other organisations or fellow colleagues as long as proper training was conducted. Elvish et al. (2016) argued that the professional affiliation may be an important characteristic of the trainers although the variability of facilitators in terms of professional background found in the other studies reviewed, indicated that this was not the case.

\section{Effectiveness of training programmes according to level of training evaluation}

\section{Studies that evaluated the participants' reactions to the programme (Level 1)}

In general, all studies that evaluated staff reactions reported a high degree of satisfaction. According to Galvin et al. (2010), programmes based on experiential and action learning seemed to be favoured by staff compared to didactic teaching sessions. However, few of the studies using traditional methods, evaluated staff reactions and thus it is not possible to determine whether this is true across all studies.

\section{Studies that evaluated changes in learning (Level 2)}


All selected studies sought to measure the effectiveness of the training programmes with regards to the extent to which learning has occurred (Level 2). Questionnaires were generally used to measure increased participants' knowledge (Elvish et al., 2015, 2016; Galvin et al., 2010; Palmer et al., 2014; Smythe et al., 2014), changes in their beliefs about challenging behaviours (Elvish et al., 2015, 2016), in self-efficacy (Smythe et al., 2014; Surr et al., 2016), in confidence (Elvish et al., 2015, 2016; Galvin et al., 2010; Palmer et al., 2014; Nayton et al., 2014), in staff burnout (Smythe et al., 2014), in satisfaction with working with dementia patients (Surr et al., 2016) and in attitudes towards persons with dementia (Galvin et al. 2010, Waugh et al., 2011; Horner et al., 2013; Banks et al., 2014; Palmer et al. 2014; Smythe et al., 2014; Teodorczuk et al., 2014; Surr et al, 2016). Most of the studies used validated quantitative tools consisting of standardised questionnaires although some authors developed their own scales (Elvish et al., 2015, Galvin et al., 2010). Whilst Elvish et al. (2015, 2016) sought to measure the psychometric properties of these new scales, Galvin et al. (2010) and Palmer et al. (2014) did not rigorously test them apart from measuring their internal consistency. Other studies opted for a mixed method using qualitative tools to evaluate changes in learning post-training. For example, to assess changes in attitudes, Teodorczuk et al. (2014) evaluated the poster produced by the staff and carried out staff interviews.

In some studies, there was a significant improvement in learning (Level 2) following training (Banks et al., 2014; Elvish et al., 2015, 2016; Galvin et al., 2010; McPhail et al., 2009; Nayton et al., 2014; Palmer et al., 2014; Teodorczuk et al., 2014; Surr et al., 2016 and Waugh et al., 2011). One study reported no significant improvement in any psychometric domain (Smythe et al., 2014). This was attributed to Type II error as a result of a small sample size. Horner et al. (2013) found that in post-training, self-efficacy improved, although there was no significant improvement in staff attitudes and knowledge. Moreover, sustainability of these changes over time was sought in only two studies. Galvin et al. (2010) showed that in one of 
the studies, perceived confidence was not sustained in one of the hospitals although a repeat of the same programme (Palmer et al., 2014) showed that learning was maintained after 3 months' follow-up. However, with a response rate at follow-up of $24 \%$, the results might have been influenced by a loss-to follow up selection bias. Consequently, relatively little is known on whether these programmes made a sustainable impact over time.

\section{Studies that evaluated change in staff behaviour and practices (Level 3)}

Only four studies measured changes in behaviour and practices following the programme (Level 3). However, these relied on self-reported data rather than from direct observation of care practices. Galvin et al. (2010) described changes in practices as 'unanticipated results' indicating that these changes were not expected and planned for prior to training commencement. Wesson \& Chapman (2010) used case notes of patients to evaluate whether documentation improved following the training and as a result seek to evaluate practice change. Conversely, Banks et al. (2014) relied on the self-reported information of change assignments that staff had to present following training to assess whether actions have been (or were planned to be) initiated in their place of work. Crabtree \& Mack (2010) used charge

nurses' feedback to evaluate whether the impact of training on the participants' behaviour and care practices.

\section{Studies that evaluated patient and family members' outcomes (Level 4)}

Level 4 evaluation, consisting of assessing training on patient/family members' outcomes, was rarely conducted. Horner et al. (2013) investigated patients two weeks before, during and two weeks after training in relation to the use of restraints, documentation of diagnosis, use of indwelling catheters, use of psychotropic drugs, length of stay and incidence of falls. However, there was no evidence that these outcomes were compared pre and post training. McPhail et al. (2009) reported a reduction in aggressive behaviour following the training 
programme. It is also not clear whether the same patients were assessed before and after training making it hard to draw any significant conclusions. Similarly, Wesson \& Chapman (2010) also found a reduction in the use of sedations from $70 \%$ to $20 \%$ when comparing 10 patients pre-training with 10 patients post-training. Nevertheless, there is no information about the methodology with which these patients were matched in order to exclude selection bias.

\section{Discussion}

\section{Summary of findings}

There has been an increased interest in dementia training programmes directed to staff working in general hospitals following recommendations from national guidelines and evidence of little or no specific staff knowledge in caring for patients with dementia. However, a systematic search of peer-reviewed studies yielded only 14 studies that fell within the inclusion criteria. None of the studies consisted of randomised controlled trials, with the majority using pre-test post-test methods. A quality assessment of the selected studies indicated that the there was considerable variability in quality. The major limitations were selection bias of the participants, small sample size and limited measures to control for confounding factors. Training programmes varied considerably between studies, in particular, on how these were developed and delivered. Besides didactic teaching, a clinical component was used in a number of studies whilst others adopted a two-level training method. Learning outcomes and level of evaluation also varied substantially, although the majority opted for evaluating the learning achieved using pre-training and post-training questionnaires. Followups to evaluate sustainability and measures of patient's outcomes were rarely performed.

\section{Quality rating and methodological issues}


The quality of the studies selected was variable with half resulting to be of poor quality. This may be attributed to the fact that, similar to residential homes (McCabe et al., 2007), there are practical problems in carrying out similar research studies in hospitals due to high staff turnover, participant bias, degenerative condition of dementia syndromes and the difficulty to maintain the results obtained over time. In addition, within-subject comparison of patients is difficult due to short length of stay making follow-up very challenging. Commenting on longterm care settings, Spector et al. (2013) recommended that future studies need to take into consideration these 'logistical barriers' and design high quality, adequately powered, multicentre studies. Based on the methodological limitations of the studies reviewed, these recommendations equally apply to studies evaluating training programmes in hospital settings. Moreover, this review showed that hospital administrators may need to engage more with mental health settings and collaborate with staff working outside of the hospital such as dementia care specialists, mental health nurses and patient's associations.

The lack of RCTs may indicate the difficulty in implementing studies that evaluate training programmes in similar settings. However, there is still debate on whether RCTs should be considered as 'gold standard' in health education research (Sullivan, 2011; Regehr, 2010). Regehr $(2010 ; 31)$ argued that in view of the complexity of health care settings there is a need to move away in health education research from 'finding a proof of simple solutions' towards a 'generation of rich understanding of the complex environments' which characterize hospital settings. This is in line with one of the recommendation proposed in the INTERDEM Manifesto that 'to ensure that the evidence for what works in dementia care can be used to transform both practice and services, there is a need to develop, implement and evaluate training and education in dementia care by drawing on the literature on diffusion of innovation, studying the obstacles, facilitators and factors that influence decisions associated with use and uptake of psychosocial interventions in practice, and addressing relevant 
personal and organisational variables...' (Moniz-Cook, 2011, p.287). Consequently, methodologies other than RCTs, including quasi-experimental studies and qualitative studies such as action research studies, are needed and may enhance ecological validity. Finally, unlike most of the studies reviewed, there is a need to carry out process evaluations to identify what factors can enhance the effectiveness of these training programmes such as organisational and staff variables and how can these be manipulated to achieve the best results. In this regard, the Medical Research Council guidance can provide a framework to clinicians and stakeholders to develop high-quality training programmes in hospital settings (Craig et al., 2008).

\section{Characteristics of the training programmes}

There was a great variability in the development and mode of delivery of the training programmes although interdisciplinary ward based, tailor-made, short sessions using experiential and active learning were the most utilized approaches. This is congruent with recommendations proposed by the Age UK (2012) which encourages the use of these methods of learning. Moreover, there is evidence in aged and dementia care literature of the relevance of incorporating reflection (Chapman \& Law, 2009), experiential learning (Chater \& Hughes, 2012; Dewar \& Nolan, 2013) and action learning (Barry \& Davies, 2006) in staff development and training. Further evidence is needed however, of how and to what extent should these learning strategies be incoroporated in staff development and training programmes.

\section{Level of training evaluation}

All studies that evaluated staff reactions to training (Level 1) found a high level of satisfaction following training programmes delivery (Level 1). This is not at all surprising considering the fact that the need for training is felt by the majority of the hospital staff 
especially by nurses (Gandesha, Souza, Chaplin \& Hood, 2012), whilst there is evidence that staff preparation at undergraduate level remains inadequate (Alzheimer Society, 2009; Scerri \& Scerri, 2013).

Most of the studies sought to evaluate changes in learning following the training programme. (Level 2). Similar to Spector, Revolta \& Orrell's review (2016), there seems to be some evidence that such programmes increase staff confidence, knowledge and attitudes towards persons with dementia. However, only one study sought to measure the effect of the training programme on staff burnout whilst none of the staff evaluated their effect on job satisfaction. Evaluating these domains could be a topic for future studies. Moreover, it is not clear whether these outcomes are sustainable over time considering that most of these studies did not follow-up staff post-intervention.

The review clearly indicates that there is still limited evidence on the effectiveness of training in changing care practices (Level 3) and influencing patient outcomes (Level 4) in hospital settings. Although numerous approaches have been used (e.g. self-reported changes) to show evidence of change in practice, there is a risk of social-desirability bias that could limit the validity of these findings (Nederhof, 1985). Moreover, there is still limited evidence on whether such training programmes impact family members, whilst the impact on patients' outcomes is characterised by a number of limitations that can considerably limit the reliability and validity of the findings. Besides the ones used in the studies reviewed, the inclusion of additional patient outcomes such as patient experiences, for example by using Dementia Care Mapping (DCM) (Bradford Dementia Group, 2005), could be used in future training programmes.

Challenges and solutions in developing and evaluating dementia training programmes in hospital settings 
The limited number of studies identified in this review can be due to the recent interest in this particular field of study, as evidenced by the fact that the majority of studies were published in the past five years. Another explanation is the challenges that accompany the development and evaluation of training programmes in hospital settings. Similar to dementia training programmes in long-term care settings (Kuske et al., 2007) organisational support is essential in the development, evaluation and sustainability of the outcomes achieved. In only two studies was continuous reinforcement and support reported. Moreover, this review is suggestive of the lack of knowledge on whether these programmes make a sustainable impact over time since most of the studies lacked a follow-up. As highlighted by some of the studies, maintaining funding and interest in such programmes may be difficult especially in hospital settings where dementia care training may not be considered a major priority. Finally, coverage of staff to attend dementia care related training is always a major challenge as also shown in a national audit of UK hospitals (Timmons et al., 2016).

Another major challenge in developing such programmes, that may not be present in longterm care settings, is how to target a diverse group of participants coming from different professions. Different solutions were sought such as carrying a training needs analysis, recruiting facilitators coming from different professions and using group and experiential learning to ensure that all participants are engaged throughout the programme irrespective of their occupation. Moreover, in the majority of the studies, the content presented was specific to the care of persons with dementia in hospital settings, not what is usually presented in long-term care settings. For example, in many of the programmes, participants were instructed on the difference between delirium, dementia and depression - topics of particular relevance within an acute hospital setting. Nonetheless, most of the programmes were framed around psychosocial models, such as Kitwood's person-centred care (Kitwood, 1997). This indicates that although person-centred dementia care in hospitals may be challenging 
(Dewing \& Dijk, 2014), attempts are being made to instil this culture of care in these settings, based on the belief that this would translate to improved quality of care of dementia patients, as has been shown in long-term care settings (Chenoweth et al., 2009).

\section{Limitations}

The review has a number of limitations. Since one of the inclusion criteria was that studies had to use a quantitative component, an appraisal of other practice development studies using other methodologies were not included. Moreover, studies written in languages other than the English language were excluded. The quality of the selected studies was variable partly due to the fact that relevant data in a number of the studies were partially described or reported. The absence of randomised controlled trials required that the quality appraisal tool used by Kmet, Lee \& Cook (2004) had to be adapted by excluding three quality criteria. Selection, attrition and response bias were common and reduced the internal validity of the selected studies. Moreover, the tool did not include a scoring guideline to categorise studies as of high or low quality, although a classification similar to Spector, Revolta \& Orrell (2016) study was used to facilitate comparison of the quality of the selected studies.

\section{Conclusion: Implications for research and clinical practice}

Hospital care of patients with dementia is challenging. Therefore, hospital staff need to be better trained to improve their knowledge, confidence and attitudes in order to change behaviours and practice that can lead to better patient outcomes. This review could be helpful to administrators, researchers, educators and clinical specialists who may be interested in developing and deliver similar training programmes in general hospital settings. 
Various theoretical models and strategies can be used in the development of the training programme, although staff satisfaction to the programme is better where experiential, reflective and active learning is used and a training need analysis is carried out. Similarly, although there are various methods of delivery that can be used, interdisciplinary ward based, tailor-made, short sessions seem to be the most favoured.

This review also indicates that although some benefits have been reported such as improved knowledge, confidence and better staff attitudes, the effectiveness of these training programmes is limited in relation to changes in staff behaviour and patient outcomes. Besides, the need for further high quality studies with extended follow-ups, it is essential to address the complexity of the factors influencing the effectiveness of these programmes by drawing from other staff development programmes and address organisational factors that can influence successful uptake and sustainability. In conclusion, training programmes need to be tailor made to hospital settings since the content, mode of delivery, outcome measures and methods of evaluation may be different from residential homes.

\section{References:}

Age UK (2012). Delivering Dignity: Securing dignity in care for older people in hospitals care homes. From: http://www.ageuk.org.uk/Global/Delivering\%20Dignity\%20Report.pdf?dtrk=true (accessed July 26, 2016)

Alzheimer's Society (2009) Counting the Cost: Caring for People with Dementia on Hospital Wards. Alzheimer's Society, London.

Banks, P., Waugh, A., Henderson, J., Sharp, B., Brown, M., Oliver, J., \& Marland, G. (2014). Enriching the care of patients with dementia in acute settings? The Dementia Champions Programme in Scotland. Dementia, 13(6), 717-736.

Barry, A., \& Davies, S. (2006). Moving forward together: evaluation of an action group involving staff and relatives within a nursing home for older people with dementia. International Journal of Older People Nursing, 1(2), 95-104. 
Bradford Dementia Group (2005) Dementia Care Mapping (DCM 8 User's Manual) University of Bradford, Bradford.

Brooker, D., Milosevic, S., Evans, S., Carter, C., Bruce, M., \& Thompson, R. (2014). RCN Development Programme: Transforming Dementia Care in Hospitals Evaluation Report. University of Worcester, Worcester.

Chapman, A., \& Law, S. (2009). Bridging the gap: an innovative dementia learning program for healthcare assistants in hospital wards using facilitator-led discussions. International Psychogeriatrics, 21(S1), S58-S63.

Chenoweth, L., King, J., Y, Brodaty H, Stein-Parbury, J., Norman, R., Haas, M. and Luscombe, G, (2009), Caring for aged dementia care resident study (CADRES) of Person-centred care, Dementia-care mapping, and usual care in dementia: A Clusterrandomised Trial, The Lancet Neurology, 8(4), 317-325.

Clissett, P., Davina, P., Rowan, H. H., and John, G. (2013). The challenges of achieving person-centred care in acute hospitals: a qualitative study of people with dementia and their families. International Journal of Nursing Studies, 50(11), 1495-1503

Crabtree, J., \& Mack, J. (2009). Developing champions to enhance the care of people with dementia in general hospitals. Nursing Times, 106(48), 13-14.

Craig, P., Dieppe, P., Macintyre, S., Michie, S., Nazareth, I., \& Petticrew, M. (2008). Developing and evaluating complex interventions: the new Medical Research Council guidance. British Medical Journal, 337, a1655.

Department of Health. (2009). Living well with dementia: a national dementia strategy. Department of Health.

Dewar, B., \& Nolan, M. (2013). Caring about caring: developing a model to implement compassionate relationship centred care in an older people care setting. International Journal of Nursing Studies, 50(9), 1247-1258.

Dewing, J., \& Dijk, S. (2014). What is the current state of care for older people with dementia in general hospitals? A literature review. Dementia, doi: 1471301213520172.

Elvish, R., Burrow, S., Cawley, R., Harney, K., Graham, P., Pilling, M., ... \& Keady, J. (2014). 'Getting to Know Me': the development and evaluation of a training programme for enhancing skills in the care of people with dementia in general hospital settings. Aging \& Mental Health, 18(4), 481-488.

Elvish, R., Burrow, S., Cawley, R., Harney, K., Pilling, M., Gregory, J., \& Keady, J. (2016). 'Getting to Know Me': The second phase roll-out of a staff training programme for supporting people with dementia in general hospitals. Dementia, 1471301216634926.

Galvin, J. E., Kuntemeier, B., Al-Hammadi, N., Germino, J., Murphy-White, M., \& McGillick, J. (2010). Dementia-friendly hospitals: Care not Crisis. An educational program designed to improve the care of the hospitalized patient with dementia. Alzheimer Disease and Associated Disorders, 24(4), 372.-379

Gandesha, A., Souza, R., Chaplin, R., \& Hood, C. (2012). Adequacy of training in dementia care for acute hospital staff: Aarti Gandesha and colleagues present the results of a national audit to assess how hospital staff from different specialties rated their 
awareness of the needs of patients with dementia. Nursing Older People, 24(4), 2631.

Hare, M., McGowan, S., Wynaden, D., Speed, G., \& Landsborough, I. (2008). Nurses' descriptions of changes in cognitive function in the acute care setting. Australian Journal of Advanced Nursing, 26(1), 21.

Hoe, R. M. N. (2015). Burdett Dementia Project Whittington Health. From: http://www.btfn.org.uk/library/directory_listings/245/Dementia\%20Project\%20Whitti ngton\%20Health.pdf (accessed March 13, 2016)

Horner, B., Watson, N., Hill, A. M., \& Etherton-Beer, C. (2013). Description, and pilot evaluation, of novel staff education to improve care of confused older inpatients. Australian Journal of Advanced Nursing 31(2), 5-12

Kirkpatrick, D. L. (2009). Implementing the Four Levels: A Practical Guide for Effective Evaluation of Training Programs: Easyread Large Edition.

Kitwood, T. (1997). Dementia reconsidered: The person comes first. Buckingham: Open University Press.

Kmet, L. M., Lee, R. C., \& Cook, L. S. (2011). Standard Quality Assessment Criteria for Evaluating Primary Research Papers from a Variety of Fields. Edmonton: Alberta Heritage Foundation for Medical Research. From: http://www.biomedcentral.com/content/supplementary/1471-2393-14-52-s2.pdf (accessed March 13, 2016)

Kuske, B., Hanns, S., Luck, T., Angermeyer, M. C., Behrens, J., \& Riedel-Heller, S. G. (2007). Nursing home staff training in dementia care: a systematic review of evaluated programs. International Psychogeriatrics, 19(5), 818-841.

Lakey, L. (2009). Counting the cost: Caring for people with dementia on hospital wards. London: Alzheimer's Society.

Light RJ, Pillemer DB. (1984) Summing up: the science of reviewing research. Cambridge, MA, USA: Harvard University Press

Lintern, T., \& Woods, R. T. (1996). The Dementia Care Practitioner Assessment (DCPA). Journal of the British Association for Service to the Elderly, 63, 12-18

Lyketsos, C.G., Jeannie-Marie, E.S. and Peter, V.R. (2000) Dementia in elderly persons in a general hospital. American Journal of Psychiatry, 157(5), 704-707.

McPhail, C., Traynor, V., Wikstrom, D., Brown, M., \& Quinn, C. (2009). Improving outcomes for dementia care in acute aged care: Impact of an education programme. Dementia, 8(1), 142-146.

McCabe, M. P., Davison, T. E., \& George, K. (2007). Effectiveness of staff training programs for behavioral problems among older people with dementia. Aging and Mental Health, 11(5), 505-519.

Moniz-Cook, E., Vernooij-Dassen, M., Woods, B., Orrell, M., \& Network, I. (2011). Psychosocial interventions in dementia care research: the INTERDEM manifesto. Aging \& Mental Health, 15(3), 283-290. 
Moyle, W., Hsu, M. C., Lieff, S., \& Vernooij-Dassen, M. (2010). Recommendations for staff education and training for older people with mental illness in long-term aged care. International Psychogeriatrics, 22(07), 1097-1106.

Moyle, W., Olorenshaw, R., Wallis, M., \& Borbasi, S. (2008). Best practice for the management of older people with dementia in the acute care setting: a review of the literature. International Journal of Older People Nursing, 3(2), 121-130.

National Collaborating Centre for Mental Health (UK). (2007). Dementia: A NICE-SCIE guideline on supporting people with dementia and their carers in health and social care. British Psychological Society. From: www.nice.org.uk/nicemedia/pdf/CG042NICEGuideline.pdf (accessed June 18, 2012)

Nayton, K., Fielding, E., Brooks, D., Graham, F. A., \& Beattie, E. (2014). Development of an education program to improve care of patients with dementia in an acute care setting. The Journal of Continuing Education in Nursing, 45(12), 552-558.

Nederhof, A. J. (1985). Methods of coping with social desirability bias: A review. European Journal of Social Psychology, 15(3), 263-280.

Palmer, J. L., Lach, H. W., McGillick, J., Murphy-White, M., Carroll, M. B., \& Armstrong, J. L. (2014). The Dementia Friendly Hospital Initiative education program for acute care nurses and staff. The Journal of Continuing Education in Nursing, 45(9), 416-424.

Popay, J., Roberts, H., Sowden, A., Petticrew, M., Arai, L., Rodgers, M., ... \& Duffy, S. (2006). Guidance on the conduct of narrative synthesis in systematic reviews. ESRC methods programme, 15(1), 47-71.

Prince, M., Wimo A., Guerchet M., Ali G-M., Wu Y-T., Prina M. (2015). World Alzheimer Report. The Global Impact of Dementia. Alzheimer's Disease International. From http://www.alz.co.uk/research/WorldAlzheimerReport2015.pdf (accessed June 17, 2015)

Pulsford D., Hall S., Keen T., Stokes F., Pusey H., Soliman A. (2003). What can higher education contribute to dementia care? Journal of Dementia Care, 11(4) 27-28

Regehr, G. (2010). It's NOT rocket science: rethinking our metaphors for research in health professions education. Medical education, 44(1), 31-39.

Royal College of Psychiatrists (2011). Report of the National Audit of Dementia Care in General Hospitals. Editors: Young J, Hood C, Woolley R, Gandesha A and Souza R. London: Healthcare Quality Improvement Partnership.

Royal College of Psychiatrists (2013). National Audit of Dementia care in general hospitals 2012-13: Second round audit report and update. Editors: Young J, Hood C, Gandesha A and Souza R. London: HQIP.

Sampson, E. L., Blanchard, M. R., Jones, L., Tookman, A., \& King, M. (2009). Dementia in the acute hospital: prospective cohort study of prevalence and mortality. The British Journal of Psychiatry, 195(1), 61-66.

Scerri, A., \& Scerri, C. (2013). Nursing students' knowledge and attitudes towards dementia-A questionnaire survey. Nurse Education Today, 33(9), 962-968. 
Scerri, C. (2015) Empowering Change. National Strategy for Dementia in the Maltese Islands 2015-2023. Parliamentary Secretariat for Rights of Persons with Disability and Active Ageing Available from: http://activeageing.gov.mt/en/Documents/book_english_book.pdf (Accessed: November 17, 2015)

Smidt, A., Balandin, S., Sigafoos, J., \& Reed, V. A. (2009). The Kirkpatrick model: A useful tool for evaluating training outcomes. Journal of Intellectual and Developmental Disability, 34(3), 266-274.

Smythe, A., Jenkins, C., Harries, M., Atkins, S., Miller, J., Wright, J., ... \& Oyebode, J. (2014). Evaluation of Dementia Training for Staff in Acute Hospital Settings: Analisa Smythe and colleagues investigated the effectiveness of a brief psychosocial intervention delivered in the workplace compared with a standard teaching approach. Nursing Older People, 26(2), 18-24.

Spector, A., Orrell, M., \& Goyder, J. (2013). A systematic review of staff training interventions to reduce the behavioural and psychological symptoms of dementia. Ageing Research Reviews, 12(1), 354-364.

Spector, A., Revolta, C., \& Orrell, M. (2016). The impact of staff training on staff outcomes in dementia care: a systematic review. International journal of geriatric psychiatry. DOI: $10.1002 /$ gps.4488.

Sullivan, G. M. (2011). Getting off the "gold standard": randomized controlled trials and education research. Journal of Graduate Medical Education, 3(3), 285-289.

Surr, C. A., Smith, S. J., Crossland, J., \& Robins, J. (2016). Impact of a person-centred dementia care training programme on hospital staff attitudes, role efficacy and perceptions of caring for people with dementia: A repeated measures study. International Journal of Nursing Studies, 53, 144-151.

Surr, C. A., Irving D., Oyebode J., Parveen S., Smith S., Drury-Payne M. \& Dennison A. (n.d.). What works in dementia training and education? A critical interpretive synthesis of the evidence. From: https://www.heacademy.ac.uk/sites/default/files/downloads/surr_what_works_in_dem entia_training.pdf (accessed November 17, 2015)

Teodorczuk, A., Mukaetova-Ladinska, E., Corbett, S., \& Welfare, M. (2014). Learning about the patient: an innovative interprofessional dementia and delirium education programme. The Clinical Teacher, 11(7), 497-502.

Timmons, S., O’Shea, E., O’Neill, D., Gallagher, P., de Siún, A., McArdle, D., ... \& Kennelly, S. (2016). Acute hospital dementia care: results from a national audit. $B M C$ Geriatrics, 16(1), 1.

Waugh, A., Marland, G., Henderson, J., Robertson, J., \& Wilson, A. (2011). Improving the care of people with dementia in hospital. Nursing Standard, 25(32), 44.

Wesson, L., \& Chapman, B. (2010). A dementia education scheme: A dynamic, multiagency strategy set up across Cornwall is improving the care of patients with memory and communication difficulties. Laura Wesson and Beverley Chapman explain how. Nursing Older People, 22(2), 22-25. 
Zekry, D., François, R. H., Raphael, G., Marie-Pierre, M.M., Jean-Pierre M., Gabriel, G., and Karl-Heinz, K. (2008) Demented versus non-demented very old inpatients: the same comorbidities but poorer functional and nutritional status. Age and Ageing, 37(1), 8389.

Figure 1. Kirkpatrick's four-level training evaluation model (adapted from Kirkpatrick, 2009)

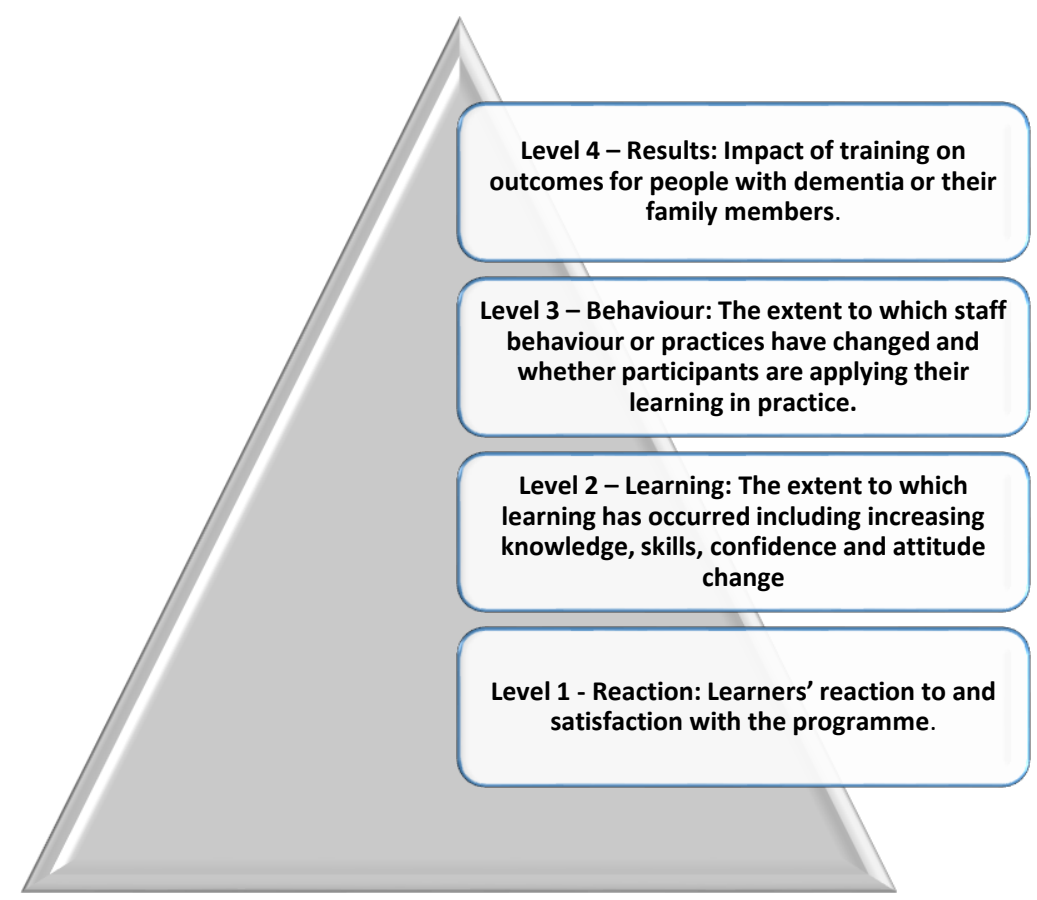


Page $\mathbf{3 0}$ of $\mathbf{4 0}$ 
Table 1. Quality rating assessment of selected studies

\begin{tabular}{|c|c|c|c|c|c|c|c|c|c|c|c|c|}
\hline & $\begin{array}{l}\text { Question / } \\
\text { objective } \\
\text { sufficiently } \\
\text { described }\end{array}$ & $\begin{array}{c}\text { Study } \\
\text { design } \\
\text { evident and } \\
\text { appropriate }\end{array}$ & $\begin{array}{c}\text { Method of } \\
\text { subject/com } \\
\text { parison } \\
\text { group } \\
\text { selection } \\
\text { described } \\
\text { and } \\
\text { appropriate }\end{array}$ & $\begin{array}{c}\begin{array}{c}\text { Subject } \\
(\text { and }\end{array} \\
\text { comparison } \\
\text { group, if } \\
\text { applicable) } \\
\text { characterist } \\
\text { ics } \\
\text { sufficiently } \\
\text { described }\end{array}$ & $\begin{array}{c}\text { Outcome } \\
\text { well defined } \\
\text { and robust } \\
\text { to } \\
\text { measureme } \\
\text { nt bias } \\
\text { Means of } \\
\text { assessment } \\
\text { reported }\end{array}$ & $\begin{array}{l}\text { Sample size } \\
\text { appropriate }\end{array}$ & $\begin{array}{c}\text { Analytic } \\
\text { methods } \\
\text { described, } \\
\text { justified } \\
\text { and } \\
\text { appropriate }\end{array}$ & $\begin{array}{c}\text { Some } \\
\text { estimate of } \\
\text { variance is } \\
\text { reported } \\
\text { for the } \\
\text { main } \\
\text { results }\end{array}$ & $\begin{array}{c}\text { Controlled } \\
\text { for } \\
\text { confoundin } \\
\quad \mathrm{g}\end{array}$ & $\begin{array}{l}\text { Results } \\
\text { reported in } \\
\text { sufficient } \\
\text { detail }\end{array}$ & $\begin{array}{l}\text { Conclusions } \\
\text { supported } \\
\text { by the } \\
\text { results }\end{array}$ & $\begin{array}{c}\text { Quality } \\
\text { Rating/ } \\
\text { Total sum } \\
\text { over the } \\
\text { total } \\
\text { possible } \\
\text { sum }\end{array}$ \\
\hline $\begin{array}{l}\text { Galvin } \\
(2010)\end{array}$ et al. & 2 & 2 & 1 & 2 & 1 & 1 & 2 & 2 & 0 & 2 & 1 & 0.72 \\
\hline $\begin{array}{l}\text { Palmer et al. } \\
(\text { 2014) }\end{array}$ & 2 & 2 & 1 & 2 & 2 & 1 & 1 & 2 & 0 & 1 & 1 & 0.68 \\
\hline $\begin{array}{ll}\text { Crabtree } & \& \\
\text { Mack (2010) } & \\
\end{array}$ & 1 & 1 & 0 & 1 & 0 & 0 & 0 & 0 & 0 & 1 & 1 & 0.23 \\
\hline $\begin{array}{l}\text { Waugh et al. } \\
\text { (2011) }\end{array}$ & 1 & 1 & 0 & 0 & 0 & 0 & 0 & 0 & 0 & 1 & 1 & 0.18 \\
\hline $\begin{array}{l}\text { Banks } \\
(2014)\end{array}$ et al. & 2 & 2 & 1 & 1 & 2 & 1 & 1 & 2 & 0 & 2 & 1 & 0.68 \\
\hline $\begin{array}{lll}\begin{array}{l}\text { Elvish } \\
(2015)\end{array} & \text { et } & \text { al. }\end{array}$ & 2 & 2 & 2 & 2 & 2 & 1 & 2 & 2 & 1 & 1 & 2 & 0.86 \\
\hline $\begin{array}{l}\text { Elvish } \\
(2016)\end{array}$ et al. & 2 & 2 & 2 & 2 & 2 & 2 & 2 & 2 & 1 & 1 & 2 & 0.91 \\
\hline Surr et al. (2016) & 2 & 2 & 1 & 2 & 2 & 1 & 2 & 2 & 1 & 2 & 2 & 0.86 \\
\hline $\begin{array}{l}\text { Smythe et al. } \\
\text { (2014) }\end{array}$ & 2 & 1 & 1 & 0 & 1 & 1 & 2 & 1 & 0 & 1 & 2 & 0.55 \\
\hline $\begin{array}{l}\text { Teodorczuk et al. } \\
\text { (2014) }\end{array}$ & 2 & 1 & 1 & 1 & 1 & 1 & 2 & 1 & 0 & 1 & 2 & 0.59 \\
\hline $\begin{array}{l}\text { Horner et al. } \\
(\mathbf{2 0 1 3})\end{array}$ & 2 & 2 & 1 & 1 & 1 & 1 & 1 & 0 & 0 & 1 & 1 & 0.50 \\
\hline $\begin{array}{l}\text { Wesson \& } \\
\text { Chapman (2010) }\end{array}$ & 1 & 0 & 1 & 1 & 1 & 1 & 0 & 0 & 0 & 1 & 1 & 0.32 \\
\hline $\begin{array}{l}\text { McPhail et al. } \\
(2009)\end{array}$ & 1 & 1 & 0 & 1 & 1 & 1 & 0 & 0 & 0 & 1 & 1 & 0.32 \\
\hline 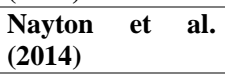 & 2 & 1 & 0 & 1 & 1 & 1 & 0 & 1 & 0 & 1 & 2 & 0.45 \\
\hline
\end{tabular}

Criteria: Yes (2), Partial (1), No (0) 
Table 2. Summary of the selected studies

\begin{tabular}{|c|c|c|c|c|c|c|c|c|}
\hline $\begin{array}{c}\text { Name of } \\
\text { Programme } \\
\text { and } \\
\text { country } \\
\end{array}$ & $\begin{array}{c}\text { Studies } \\
\text { adopting the } \\
\text { programme }\end{array}$ & Participants & $\begin{array}{l}\text { Development and key components } \\
\text { of the programme }\end{array}$ & $\begin{array}{l}\text { Method of evaluation used } \\
\text { and } \\
\text { outcomes measured }\end{array}$ & Main Findings & Lessons learned & $\begin{array}{l}\text { Quality } \\
\text { score }\end{array}$ & $\begin{array}{c}\text { Level of } \\
\text { training } \\
\text { evaluation }\end{array}$ \\
\hline $\begin{array}{l}\text { Dementia } \\
\text { Friendly } \\
\text { Hospital } \\
\text { Initiative } \\
\text { (DFHI) } \\
\text { USA }\end{array}$ & $\begin{array}{l}\text { Galvin et al. } \\
(2010)\end{array}$ & $\begin{array}{l}540 \text { nurses and } \\
\text { direct-care staff } \\
\text { (social workers, } \\
\text { pastoral care, } \\
\text { discharge } \\
\text { planner and } \\
\text { physical } \\
\text { therapists in } 4 \\
\text { community } \\
\text { hospitals }\end{array}$ & $\begin{array}{l}\text { The programme was based on a } \\
\text { publication 'Try this: Best Practices } \\
\text { in Nursing Care for Persons with } \\
\text { dementia' by Hartford Institute for } \\
\text { Geriatric Nursing and following } \\
\text { focus groups with hospital staff. } \\
\text { Training was mainly didactic with } \\
\text { group learning consisting of } 5 \\
\text { modules lasting } 7 \text { hours in all. }\end{array}$ & $\begin{array}{l}\text { Pre-test, post-test with } \\
\text { follow-up after } 120 \text { days } \\
\text { - Outcome evaluation: Staff } \\
\text { knowledge, confidence, } \\
\text { attitudes, and perceived } \\
\text { difficulty in working with } \\
\text { patients with dementia } \\
\text { - One-time process } \\
\text { evaluation: Staff perception } \\
\text { about whether programme } \\
\text { has achieved its objectives }\end{array}$ & $\begin{array}{l}\text { Primary outcome: } \\
\text { Significant improvements } \\
\text { in knowledge, confidence } \\
\text { and attitudes before and at } \\
\text { end of the workshop. A } \\
\text { decrease in knowledge and } \\
\text { confidence in one of the } \\
\text { four hospitals after } 120 \\
\text { days' follow-up. } \\
\text { Other outcomes: Staff } \\
\text { reported more family } \\
\text { involvement and the need } \\
\text { for better communication } \\
\text { skills and environmental } \\
\text { adaptations. Activity kids } \\
\text { were introduced in one of } \\
\text { the hospital. Introduction } \\
\text { of volunteers in another } \\
\text { hospital. }\end{array}$ & $\begin{array}{l}\text { Sustainability of long- } \\
\text { lasting change is } \\
\text { dependent on continued } \\
\text { in-service training and } \\
\text { hospital wide-systematic } \\
\text { change } \\
\text { Outcomes measures may } \\
\text { be difficult to obtain } \\
\text { without administrative } \\
\text { support. }\end{array}$ & 0.77 & Level 1,2,3 \\
\hline $\begin{array}{l}\text { Dementia } \\
\text { Friendly } \\
\text { Hospital } \\
\text { Initiative } \\
\text { (DFHI) } \\
\text { USA }\end{array}$ & $\begin{array}{l}\text { Palmer, } \\
\text { McGillick, } \\
\text { Armstrong } \\
\text { (2014) }\end{array}$ & $\begin{array}{l}355 \text { direct care } \\
\text { staff, } 62 \% \text { being } \\
\text { nurses, } 85 \% \text { of } \\
\text { the participants } \\
\text { work in five } \\
\text { hospitals }\end{array}$ & $\begin{array}{l}\text { Phase } 3 \text { of the DFHI programme } \\
\text { developed by Galvin et al with the } \\
\text { addition of active learning, use of } \\
\text { videos and involvement of } \\
\text { administrators. Staff were also } \\
\text { asked to sign a pledge to implement } \\
\text { what they have learned. }\end{array}$ & Same as in Galvin et al & $\begin{array}{l}\text { Primary outcome: } \\
\text { Significant improvement in } \\
\text { knowledge, confidence, } \\
\text { attitudes and practices as } \\
\text { obtained from a pre-post } \\
\text { questionnaire. } \\
\text { Other outcomes Staff were } \\
\text { highly satisfied with the } \\
\text { programme in terms of the } \\
\text { practical applicability of } \\
\text { the content and learning } \\
\text { methods used. However, } \\
\text { more interactive activities } \\
\text { were suggested. }\end{array}$ & $\begin{array}{l}\text { Collaboration between } \\
\text { local NGOs, academics } \\
\text { and hospital } \\
\text { administrators was } \\
\text { fundamental for success. } \\
\text { Certification may be } \\
\text { provided to participants } \\
\text { so that they are duly } \\
\text { acknowledged } \\
\text { Financial sustainability } \\
\text { of such programmes is a } \\
\text { major concern }\end{array}$ & 0.68 & Level 1,2 \\
\hline
\end{tabular}




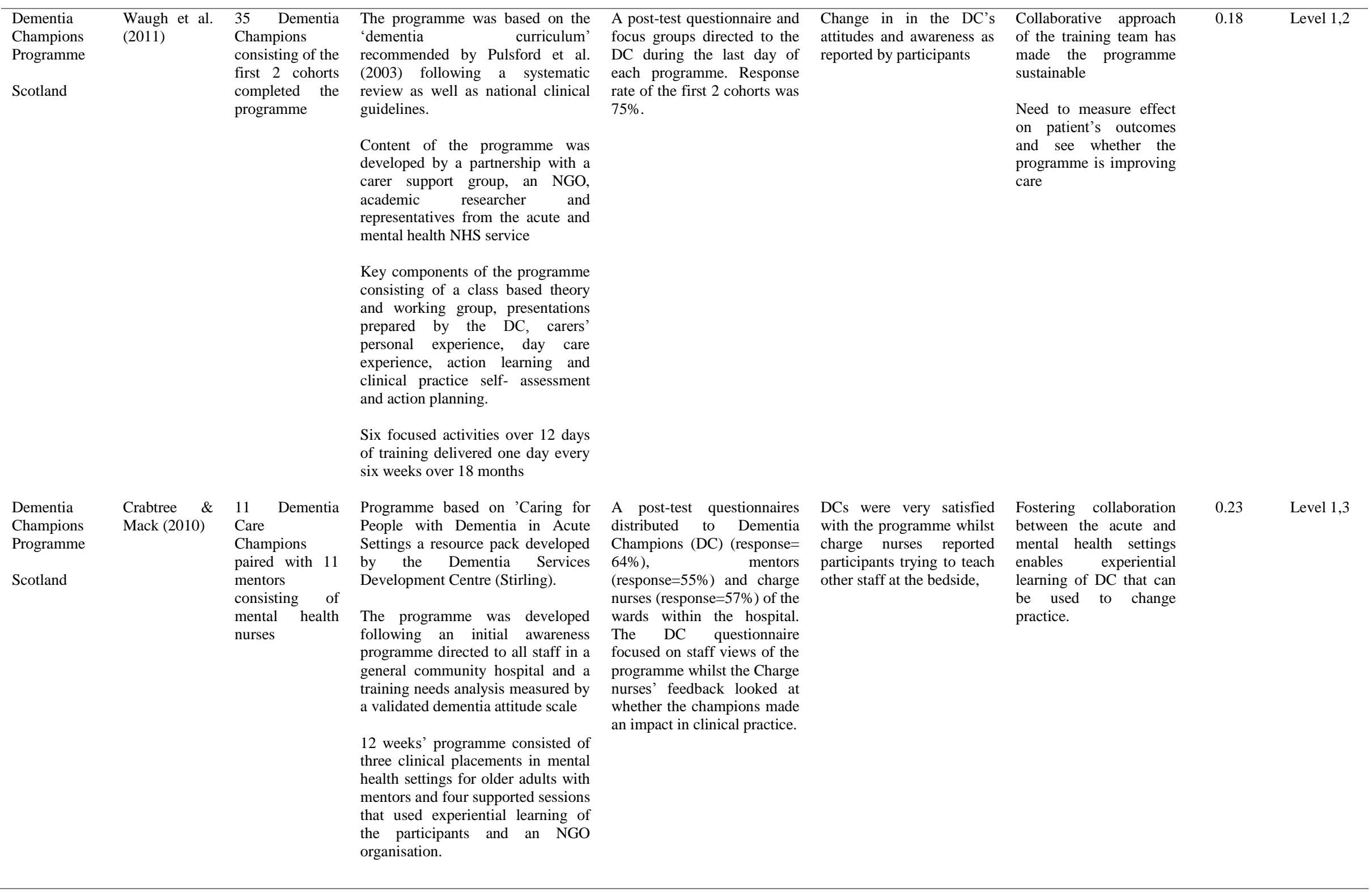




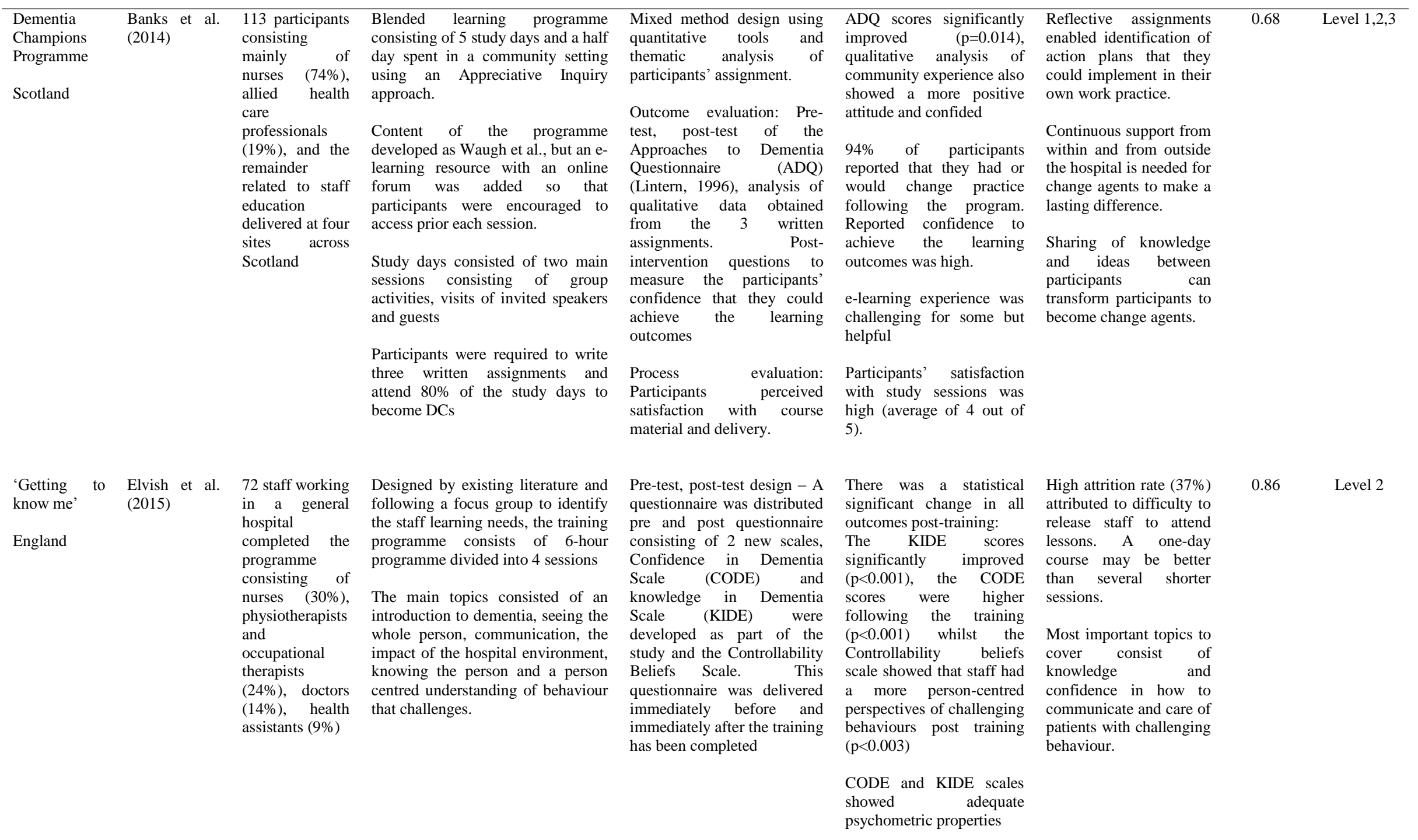




\begin{tabular}{|c|c|c|c|c|c|c|c|c|}
\hline $\begin{array}{l}\text { 'Getting, to } \\
\text { know me' } \\
\text { England }\end{array}$ & $\begin{array}{l}\text { Elvish et al. } \\
(2016)\end{array}$ & $\begin{array}{l}607 \text { participants } \\
\text { completed the } \\
\text { programme but } \\
480 \\
\text { questionnaires } \\
\text { were collected } \\
\text { with half of the } \\
\text { participants } \\
\text { being nurses }\end{array}$ & $\begin{array}{l}\text { Programme aimed to address the } \\
\text { limitations in Elvish et al (2015) } \\
\text { study by developing a 'train the } \\
\text { trainers' programme so that } \\
\text { academic staff trained hospital staff } \\
\text { who in turn trained their own staff. }\end{array}$ & $\begin{array}{l}\text { Same as in Elvish et al } \\
(2015)\end{array}$ & $\begin{array}{l}\text { As in Elvish (2015), scales } \\
\text { maintained good } \\
\text { psychometric properties } \\
\text { whilst statistical significant } \\
\text { change was found between } \\
\text { pre-post training in all } \\
\text { outcomes measures } \\
\text { (CODE: p=0.001, KIDE: } \\
\text { p }<0.001, \text { Controllability } \\
\text { beliefs scale: p=0.001) } \\
\text { with moderate to large } \\
\text { effect size }\end{array}$ & 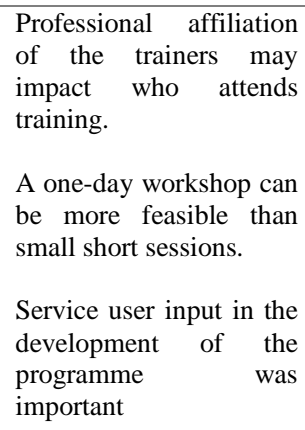 & 0.91 & Level 2 \\
\hline $\begin{array}{l}\text { Person- } \\
\text { centred care } \\
\text { Training for } \\
\text { Acute } \\
\text { Hospitals } \\
\text { (PCTAH) } \\
\text { England }\end{array}$ & $\begin{array}{l}\text { Surr et al. } \\
(2016)\end{array}$ & $\begin{array}{l}\text { A convenience } \\
\text { sample of } 41 \\
\text { acute hospital } \\
\text { staff } 86 \% \text { being } \\
\text { nurses }\end{array}$ & $\begin{array}{l}\text { The programme consisted of two } \\
\text { levels - a half-day foundation } \\
\text { programme (seven } 30 \text { minute } \\
\text { sessions) a three-day Intermediate } \\
\text { level delivered over a } 3 \text { to 4-month } \\
\text { period. } \\
\text { The half day programme covered } \\
\text { person-centred care, types and } \\
\text { impact of dementia, identification } \\
\text { of and meeting people's emotional } \\
\text { needs, effective communication, the } \\
\text { impact of the physical environment, } \\
\text { identifying and meeting physical } \\
\text { health needs and redefining and } \\
\text { supporting challenging behaviours. } \\
\text { The intermediate programme } \\
\text { provided a more in depth } \\
\text { knowledge of the contents covered } \\
\text { in the Foundation programme. } \\
\text { The programme was developed by } \\
\text { the authors based on knowledge } \\
\text { gaps obtained from a literature } \\
\text { review and discussion with nurse } \\
\text { managers }\end{array}$ & $\begin{array}{l}\text { A pre-test, post-test } \\
\text { questionnaire was distributed } \\
\text { immediately before the } \\
\text { programme (T1) and } \\
\text { repeated after completing the } \\
\text { Foundation level (T2) (4-6 } \\
\text { weeks post-baseline) and } \\
\text { after the Intermediate level } \\
\text { training at T3 (3-4 months' } \\
\text { post-baseline). } \\
\text { The questionnaire assessed } \\
\text { staff attitudes towards } \\
\text { persons with dementia using } \\
\text { the Approaches to Dementia } \\
\text { Questionnaire (ADQ), the } \\
\text { staff experience of working } \\
\text { with dementia residents' } \\
\text { scale (SEWR) and the Caring } \\
\text { Efficacy Scale (CES) to } \\
\text { measure the staff ability to } \\
\text { develop caring relationships. }\end{array}$ & $\begin{array}{l}\text { The programme produced } \\
\text { a significant positive } \\
\text { change in all three } \\
\text { outcome measure } \\
\text { following the intermediate } \\
\text { training programme. Staff } \\
\text { satisfaction significantly } \\
\text { increased between T1 and } \\
\text { T3 and between T2 and T3 } \\
\text { but not between T1 and } \\
\text { T2. Moreover, although } \\
\text { ADQ personhood subscale } \\
\text { score improved between } \\
\text { T1 and T3 (p<0.001) and } \\
\text { between T2 and T3 } \\
(p<0.001) \text { there was no } \\
\text { significant difference } \\
\text { between T1 and T2 } \\
\text { (p=0.1). Similarly, self- } \\
\text { efficacy }\end{array}$ & $\begin{array}{l}\text { Foundation level training } \\
\text { may be adequate for } \\
\text { awareness raising. } \\
\text { Further training is } \\
\text { required to influence } \\
\text { staff feelings of caring } \\
\text { efficacy and satisfaction. } \\
\text { Length of time since } \\
\text { training completion can } \\
\text { influence outcomes. } \\
\text { Therefore, longer } \\
\text { follow-up may be } \\
\text { required to measure if } \\
\text { the impact have been } \\
\text { sustained. }\end{array}$ & 0.86 & Level 2 \\
\hline
\end{tabular}




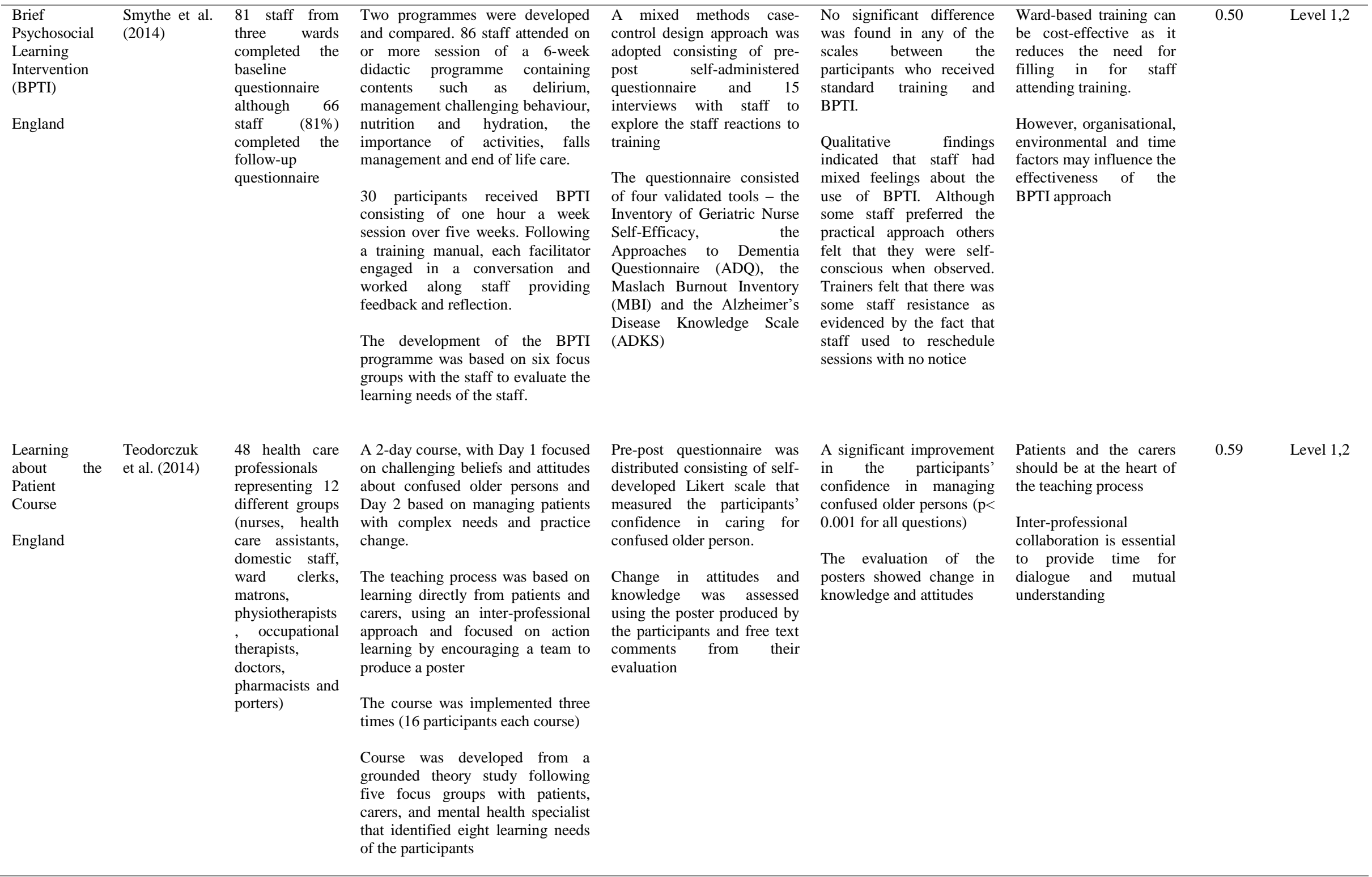

Page $\mathbf{3 6}$ of $\mathbf{4 0}$ 


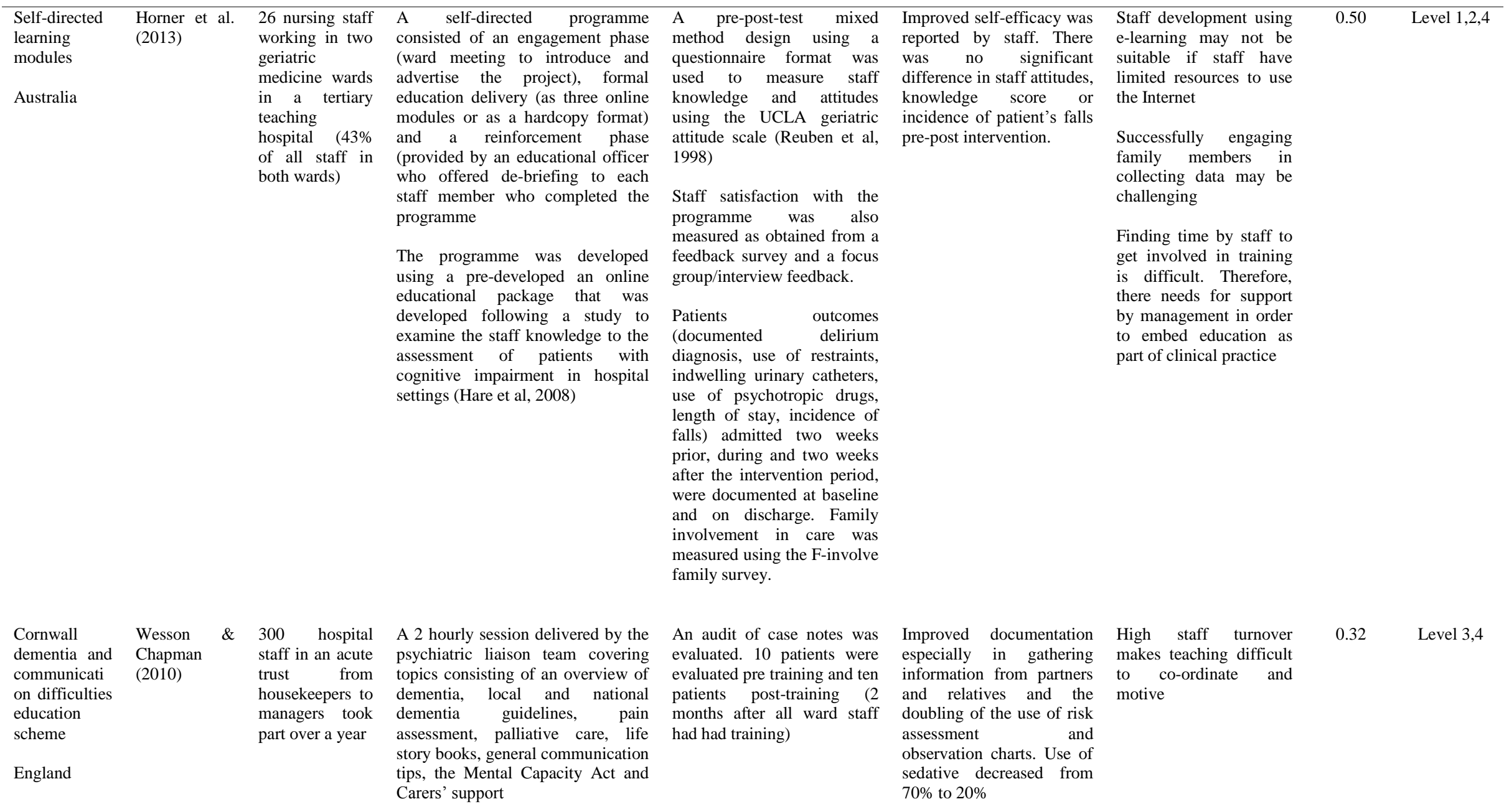




\begin{tabular}{|c|c|c|c|c|c|c|c|c|}
\hline $\begin{array}{l}\text { Dementia } \\
\text { education } \\
\text { programme } \\
\text { Australia }\end{array}$ & $\begin{array}{l}\text { McPhail et al. } \\
\text { (2009) }\end{array}$ & 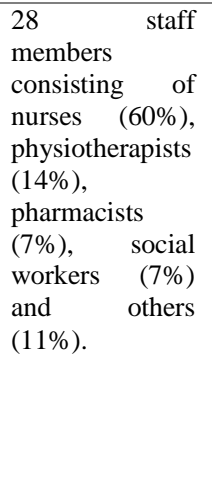 & $\begin{array}{l}10 \text { sessions (one hour every week } \\
\text { for } 10 \text { weeks) consisting of mainly } \\
\text { didactic teaching. Contents included } \\
\text { topics related to what is dementia, } \\
\text { difference between dementia, } \\
\text { depression and delirium, } \\
\text { Behavioural management using a } \\
\text { behaviour log, medications in the } \\
\text { elderly, sedation policy, attitudinal } \\
\text { change, sexual disinhibition, } \\
\text { restraint, Poole's Algorithm and } \\
\text { social management in acute care. } \\
\text { Sessions were developed following } \\
\text { a learning needs analysis of all staff } \\
\text { using a survey }\end{array}$ & $\begin{array}{l}\text { Post-training questionnaire } \\
\text { administered to staff } \\
\text { perceptions whether the } \\
\text { sessions have helped them to } \\
\text { develop the skills to caring } \\
\text { for people with dementia } \\
\text { using both closed and open } \\
\text { ended questions. Impact on } \\
\text { dementia knowledge and } \\
\text { skills was measured using a } \\
\text { post-test survey }\end{array}$ & $\begin{array}{l}64 \% \text { of attendees reported } \\
\text { the sessions being } \\
\text { beneficial for enhancing } \\
\text { their skills in caring for } \\
\text { patients with dementia in } \\
\text { acute care. Awareness of } \\
\text { pain and environmental } \\
\text { factors contributing to } \\
\text { behavioural challenges } \\
\text { improved. There was also a } \\
\text { reduction in aggressive } \\
\text { behaviour } 4 \text { months post- } \\
\text { training ( } 3 \text { incidents) when } \\
\text { compared to incidents pre- } \\
\text { training (12 incidents) }\end{array}$ & $\begin{array}{l}\text { Educational programme } \\
\text { helped in transforming a } \\
\text { medical/surgical unit } \\
\text { into a specialist } \\
\text { aged care service }\end{array}$ & 0.32 & Level $1,2,4$ \\
\hline $\begin{array}{l}\text { 'View From } \\
\text { Here: skills in } \\
\text { Dementia } \\
\text { Care for } \\
\text { Acute } \\
\text { Settings' } \\
\text { Australia }\end{array}$ & $\begin{array}{l}\text { Nayton et al. } \\
\text { (2014) }\end{array}$ & $\begin{array}{l}\text { The programme } \\
\text { was delivered to } \\
49 \text { participants } \\
\text { from two acute } \\
\text { wards the } \\
\text { majority (45) } \\
\text { consisting of } \\
\text { nurses. }\end{array}$ & $\begin{array}{l}\text { The programme consisted of an } \\
\text { outcome-based, microteaching } \\
\text { approach with a theoretical and a } \\
\text { practical component. Seven } \\
\text { sessions (repeated four times) were } \\
\text { developed dwelling on } \\
\text { neurobiology and person-centred } \\
\text { care, communication strategies, } \\
\text { information gathering, approaches } \\
\text { to pain assessment, activities for the } \\
\text { inpatient setting, behavioural } \\
\text { observation and pharmacology and } \\
\text { the acute care environment. } \\
\text { The programme was developed } \\
\text { following expectations' regarding } \\
\text { training outcomes, an audit of staff } \\
\text { perceived attitudes and knowledge, } \\
\text { an environmental review, } \\
\text { discussion with caregivers, a review } \\
\text { of the literature, expert opinion and } \\
\text { reflection and evaluation of each } \\
\text { session. An additional 90-minute } \\
\text { workshop was attended by the } \\
\text { nurses' unit management, dementia } \\
\text { champions identified from the staff } \\
\text { attending the programme, the } \\
\text { facilitator of the and developer of } \\
\text { the sessions, to discuss how to make } \\
\text { the changes sustainable }\end{array}$ & $\begin{array}{l}\text { Each session was evaluated } \\
\text { using a 7-point Likert scale } \\
\text { to see whether staff had } \\
\text { gained confidence to apply } \\
\text { what they had thought in } \\
\text { practice. A final survey to } \\
\text { evaluate the staff overall } \\
\text { satisfaction with the sessions } \\
\text { was completed after all } \\
\text { sessions. }\end{array}$ & $\begin{array}{l}\text { There was an overall } \\
\text { satisfaction with the } \\
\text { programme (mean=3.77 on } \\
\text { a } 5 \text { point Likert scale). } \\
\text { Moreover, the evaluation } \\
\text { after each session indicated } \\
\text { that staff confidence was } \\
\text { positive (means ranged } \\
\text { from } 5.6 \text { to } 6.3 \text { on a } 7 \text { point } \\
\text { Likert scale) }\end{array}$ & 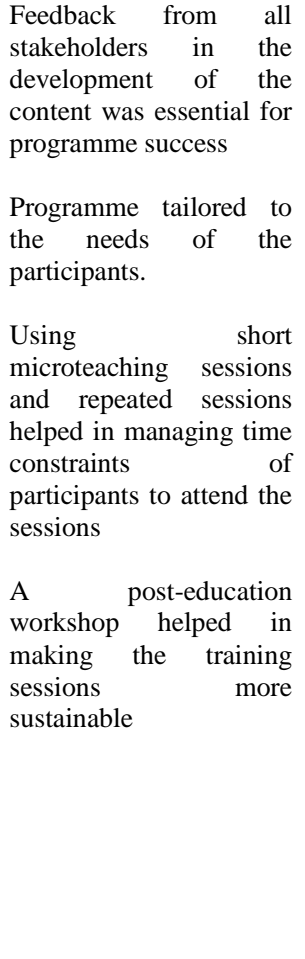 & 0.45 & Level 1,2 \\
\hline
\end{tabular}




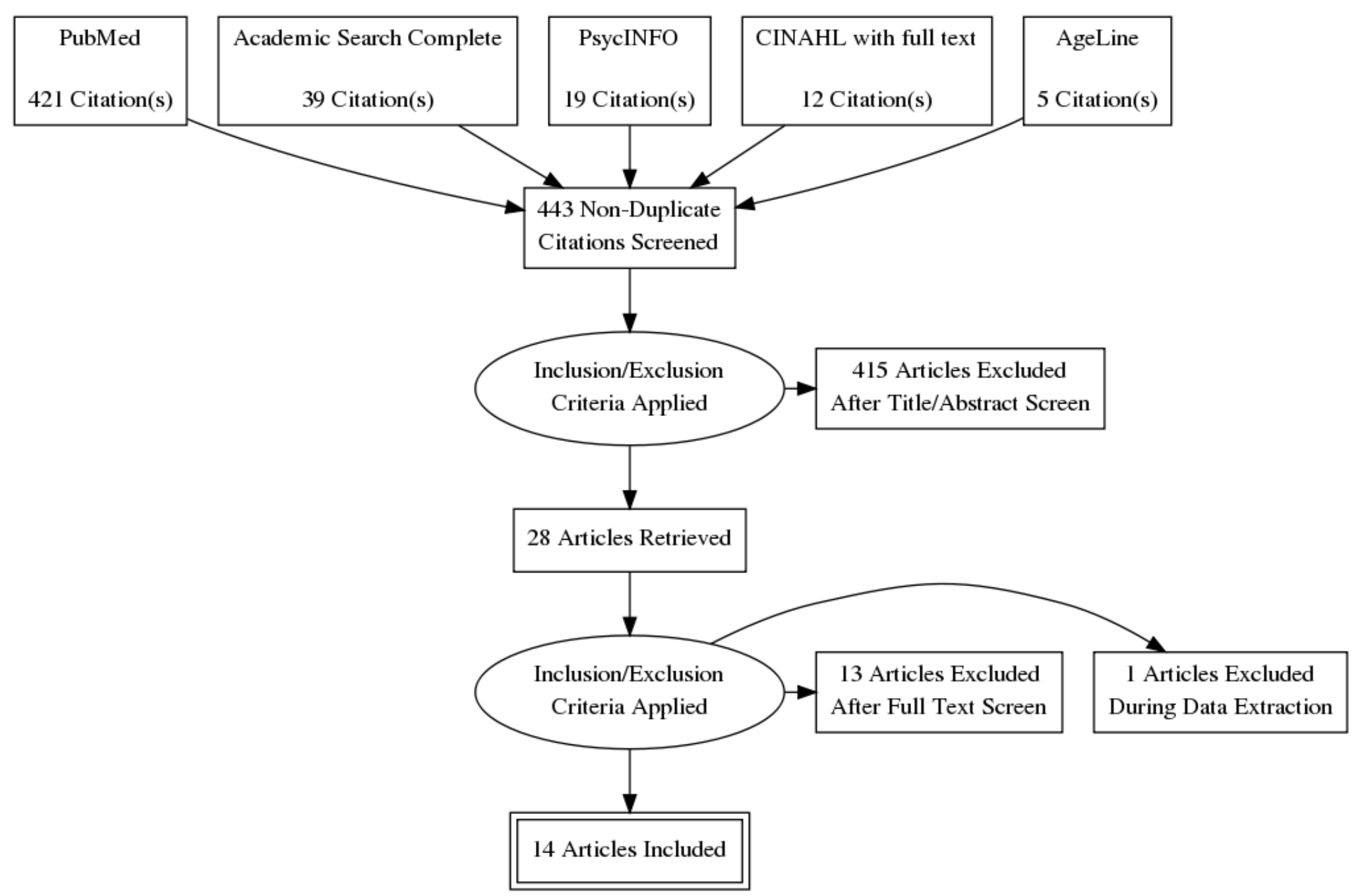

Figure 2. Flowchart of the search strategy 


\section{Appendix: Search trail}

\begin{tabular}{|c|c|c|c|}
\hline Database & Combined keywords & $\underline{\underline{\text { Search }}}$ & $\frac{\text { Retrieved articles }}{\frac{\text { after excluding }}{\text { duplicates }}}$ \\
\hline \multirow{2}{*}{ PubMed } & Dementia AND hospital AND training AND education AND evaluation & 442 & \multirow{2}{*}{421} \\
\hline & Alzheimer AND hospital AND training AND education AND evaluation & 182 & \\
\hline \multirow{2}{*}{$\begin{array}{l}\text { Academic Search } \\
\text { Complete }\end{array}$} & Dementia AND hospital AND training AND education AND evaluation & 40 & \multirow{2}{*}{39} \\
\hline & Alzheimer AND hospital AND training AND education AND evaluation & 6 & \\
\hline \multirow{2}{*}{ PsychInfo } & Dementia AND hospital AND training AND education AND evaluation & 20 & \multirow[b]{2}{*}{19} \\
\hline & Alzheimer AND hospital AND training AND education AND evaluation & 4 & \\
\hline \multirow{2}{*}{ CINAHL } & Dementia AND hospital AND training AND education AND evaluation & 12 & \multirow{2}{*}{12} \\
\hline & Alzheimer AND hospital AND training AND education AND evaluation & 0 & \\
\hline \multirow{2}{*}{ AgeLine } & Dementia AND hospital AND training AND education AND evaluation & 5 & \multirow{2}{*}{5} \\
\hline & Alzheimer AND hospital AND training AND education AND evaluation & 0 & \\
\hline
\end{tabular}

